\title{
Performance and emission characteristics of a diesel engine runs with corn oil biodiesel blends and air pre-heater
}

\author{
P. Shanmughasundaram*,V. Gopinath**, P. Suresh*** \\ *Department of Automobile Engineering, Karpagam University, Karpagam Academy of Higher Education, \\ Coimbatore-21, India, E-mail: drpshanmughasundaramauto@karpagamuniversity.edu.in \\ **Karpagam University, Karpagam Academy of Higher Education, Coimbatore, India, E-mail:vgopinathme@gmail.com \\ ***Karpagam College of Engineering, Coimbatore, India
}

cross $^{\text {ref }}$ http://dx.doi.org/10.5755/j01.mech.23.3.14853

\section{Introduction}

Usage and demand of fossil fuel has been increasing day by day. As the fossil fuel resources are gradually diminishing every year, various researchers have been trying to find the suitable alternate energy sources and fuels particularly vegetables oils. The alternative to diesel fuel should be technically and economically viable, environmental friendly, and readily available. Biodiesel which is derived from the vegetable oils through the transesterificationprocess, have properties similar to that of diesel fuel.Bio fuels such as Jatropha, corn oil, castor oil, sunflower and palm oil are considered as an alternative fuels for diesel [15]. The performance of diesel engine can be improved through preheating the inlet air by reusing the waste heat energy from the exhaust gas and the fuel consumption can be reduced drastically $[16,21]$.High viscosity of the vegetable oil affects the atomization of fuel, sticking the piston ring and choking the injection system. Transesterification is the best method to reduce the viscosity of the oil [18]. The performance of engine using biodiesels like linseed, mahua, rice bran, and LOME are giving better results than straight vegetable oils [5].Brake specific fuel consumption tends to increase with higher percentage of jatropha biodiesel whereas brake thermal efficiency tends to decrease with the increased percentage of biodiesel in the blends. $\mathrm{CO}$ and $\mathrm{HC}$ emissions are improved with the addition of biodiesel. NOx emission is found to be increased with biodiesel compared to mineral diesel [1]. Results revealed that the low concentration blends (particularly for B20 and lower blends) in terms of engine performance and environmentally friendly emissions could be recognized as the potential candidates [6]. The performance of engine using biodiesel of vegetable oils like rice bran oil, linseed oil, palm oil, soybean oil and olive oil are giving better result than the pure diesel $[3,8,14]$.

As biodiesel contains more oxygen molecules, which enhances better combustion, emissions like CO, HC and particulates tend to reduce drastically [2]. The experiment results revealed that $\mathrm{CO}$ and smoke tends to decrease when the engine fuelled with rapeseed oil and hazelnut oil, but NOx emission increased [4]. Coconut oil and castor oil are produced less thermal efficiency while emissions like carbon dioxide, unburned hydrocarbon decreased, but NOx increased as compared to diesel. [9-11]. Increasing the inlet air temperature causes reduction in ignition delay period, which reduces the premixed burning phase and decreases the engine cylinder temperature thereby reducing in $\mathrm{NOx}$ emission. Better combustion is achieved due to increase in air inlet temperature, which also reduces the formations of unburned $\mathrm{HC}$ and $\mathrm{CO}_{2}$ [20].

Exhaust gas recirculation (EGR) method can be used to reduce the NOx emission [13]. The main function of EGR is to re-circulate the part of exhaust gas to engine inlet air and to reduce the NOx emission rate [7]. With increase in the percentage of both biodiesel and EGR, carbon monoxide (CO) and hydrocarbon (HC) emissions were reduced considerably. CO emission reduction of $17-19 \%$ and $\mathrm{HC}$ emission reduction of 23-25\% were observed with biodiesel with fuel additive when compared to that of diesel and NOx emissions were reduced by $33-35 \%$ when compared to pure diesel without EGR [19].

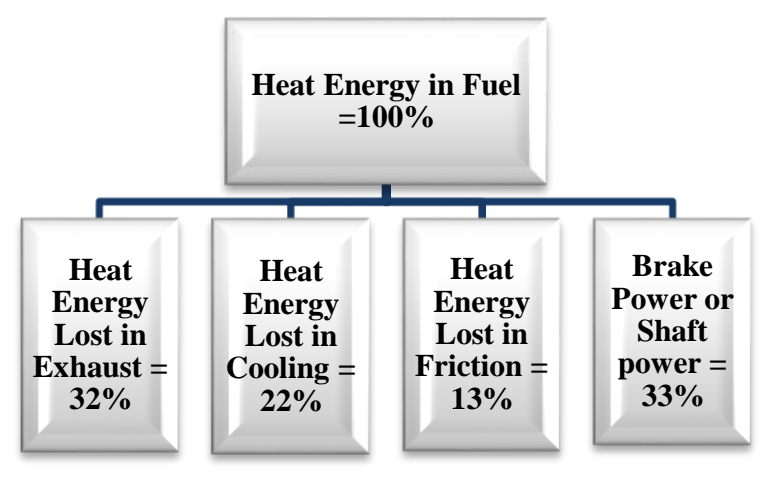

Fig. 1 Typical Energy Split in IC engine

Fig. 1 shows the typical energy split in IC engine. The atmospheric air temperature is increasing due to major heat release in exhaust gas from the diesel engines. In IC engine around $32 \%$ of heat energy released through exhaust gases, which will affect the ecosystem of the living things. We introduced air pre-heater in IC engine to recover the heat in exhaust gas. The waste heat in exhaust gas is passed to heat exchanger at one end and atmospheric air at other end, the heat energy will transfer from exhaust gas to inlet air. Higher inlet air temperature causes lower ignition delay which prevents the formation of NOx. Easy vaporization and better mixing of air and fuel occur due to warm up of inlet air, which causes lower $\mathrm{CO}$ emission.

The cultivation of corn (maize) is increasing every year. The corn oil methyl ester is non-toxic and quickly biodegradable. Straight corn oil using in engine will decrease the power output and thermal efficiency due to high viscosity. The best chemical method to reduce the viscosity of corn oil is called transesterification process. 
In the study, the engine performance and emissions characteristics investigated with different blends of corn bio diesel and diesel.

\section{Methodology}

\subsection{Air pre heater}

In this work, an external air pre-heater set up is attached to the engineas shown in Fig. 2. The main purpose of air pre-heater is to extract the heat energy from the exhaust gas and used to improve the engine performance and reduce the exhaust emission by the way of increasing the inlet air temperature. Air pre-heater (APH) is one of the most effective methods for increasing thermal efficiency and reducing NOx emission of diesel engines.

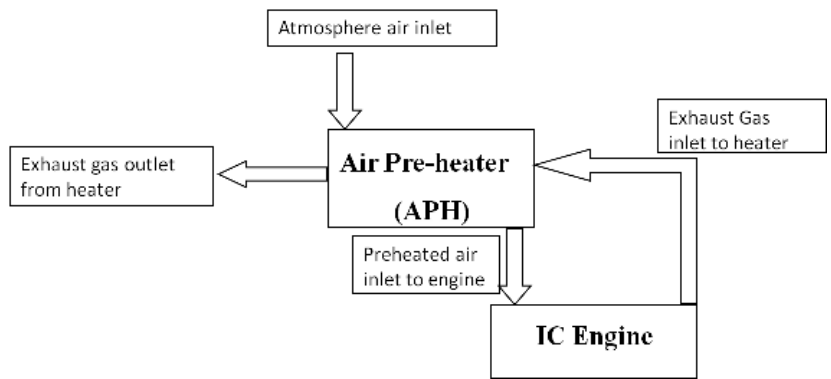

Fig. 2 A typical waste heat energy recovery system with Air pre-heater

\subsection{Preparation of biodiesel}

The viscosity of vegetable oil can be reduced by transesterification process which converts the straight vegetable oil to biofuel. In this process, vegetable oil of 1 liter and sodium hydroxide of 13 grams and methanol of 0.2 liter are taken in a separate flask. The sodium hydroxide and the methanol are stirred thoroughly. The corn oil is mixed with the solution and stirred at constant speed for 60 minutes with the temperature of $65^{\circ} \mathrm{C}$. After the time of 60 minutes, the solution was poured in a separate flask and allowed 5 hours for setting. Due to density difference the glycerin settles at the bottom and the methyl ester of corn oil floats at the top. The methyl ester of corn oil (biodiesel) was separated from the glycerin. The properties of corn oil biodiesel and diesel are given in Table 1 .

Table 1

Properties of corn oil biodiesel and diesel

\begin{tabular}{|l|c|c|}
\hline \multicolumn{1}{|c|}{ Properties } & Corn oil (Biodiesel) & Diesel \\
\hline Calorific Value, $\mathrm{KJ} / \mathrm{kg}$ & 39500 & 42000 \\
\hline Flash Point, ${ }^{\circ} \mathrm{C}$ & 153 & 57 \\
\hline Fire Point, ${ }^{\circ} \mathrm{C}$ & 161 & 65 \\
\hline Viscosity at $40^{\circ} \mathrm{C}, \mathrm{CST}$ & 8.6 & 5 \\
\hline Density, $\mathrm{kg} / \mathrm{m}^{3}$ & 875 & 853 \\
\hline Specific Gravity & 0.875 & 0.853 \\
\hline
\end{tabular}

\subsection{Experimental setup}

Experimental investigation is carried out on a four stroke, constant speed, direct injection, single cylinder compression ignition engine. The mass flow rate of air is measured by using manometer. The temperature of inlet airand exhaust gas are measured by using thermocouple and the consumption of fuel is measured by using burette. The engine specification is given in Table 2 .

Table 2

Engine Specification

\begin{tabular}{|l|l|}
\hline \multicolumn{1}{|c|}{ Parameter } & \multicolumn{1}{c|}{ Specification } \\
\hline Type & Four stroke, Single cylinder diesel engine \\
\hline Stroke in, mm & 203 \\
\hline Bore in, mm & 127 \\
\hline Rated power, HP & 10.7 \\
\hline Compression ratio & $16: 1$ \\
\hline Rated, rpm & 750 \\
\hline
\end{tabular}

Emission values for all tests are started from zero, Uncertainty $\pm 5 \%$.

\section{Result and discussion}

Tests were conducted with different loads at the two different inlet air temperatures of $35^{\circ} \mathrm{C}$ and $50^{\circ} \mathrm{C}$ with biodiesel blends having $100 \% \mathrm{D}, 90 \% \mathrm{D}+10 \% \mathrm{CME}, 80 \%$ D+20\% CME, 70\% D+30\% CME and 60\% D+40\% CME. Before taking the measurement, the engine was run for 15 minutes to attain steady state. The fuel consumption was calculated on time taken for consumption of $25 \mathrm{cc}$ of fuel. The composition of biodiesel blend of $90 \% \mathrm{D}+10 \% \mathrm{CME}$ as taken by volume/volume ratio of $22.5 \mathrm{cc}$ of diesel and $2.5 \mathrm{cc}$ of biodiesel, similarly for $80 \% \mathrm{D}+20 \% \mathrm{CME}$ as $20 \mathrm{cc}$ of diesel and $5 \mathrm{cc}$ of biodiesel, $70 \% \mathrm{D}+30 \% \mathrm{CME}$ as $17.5 \mathrm{cc}$ of diesel and $7.5 \mathrm{cc}$ of biodiesel and $60 \% \mathrm{D}+40 \% \mathrm{CME}$ as $15 \mathrm{cc}$ of diesel and $10 \mathrm{cc}$ of biodiesel.

\subsection{Indicated diagram ( $\mathrm{P}-\mathrm{V}$ diagram $)$}

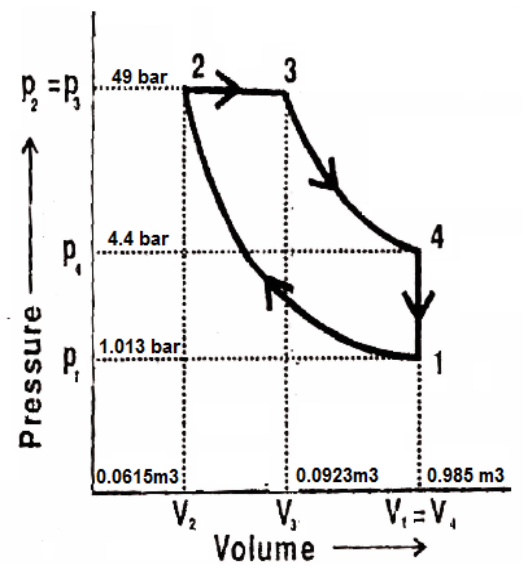

Fig. 3 Typical Indicated diagram

Fig. 3 shows the typical indicated diagram of diesel cycle. The process 1-2 is an isentropic compression process in which the inlet air (Pressure of 1.013 bar and volume of $0.985 \mathrm{~m}^{3}$ ) is compressed to pressure of 49 bar and volume is reduced to $0.0615 \mathrm{~m}^{3}$. The process $2-3$ is a constant pressure heat addition process. The process 3-4 is an isentropic expansion process, in which the pressure is reduced to 4.4 bar and volume is increased to $0.985 \mathrm{~m}^{3}$. The process $4-1$ is a constant volume heat rejection process, in which the volume remains constant and pressure reduced to atmospheric condition. 


\subsection{Cylinder pressure}



Fig. 4 Variation of cylinder pressure with crank angle

Fig. 4 shows the variation of cylinder pressure with crank angle for diesel, corn oil methyl ester and its blends at full load condition. The cylinder pressure49bar, 51 bar, 52 bar, 53.5 bar and 55.1 bar were recorded for $100 \% \mathrm{D}$, 90\%D+10\%CME， 80\%D+20\% CME， 70\%D+30\%CME and $60 \% \mathrm{D}+40 \% \mathrm{CME}$ respectively. The cylinder pressure is higher for $60 \% \mathrm{D}+40 \% \mathrm{CME}$ than that of $100 \%$ diesel and other blends. This could be attributed to the fact that the more oxygen content present in methyl ester fuel which enhances the complete combustion.

\subsection{Brake thermal efficiency (BTE)}

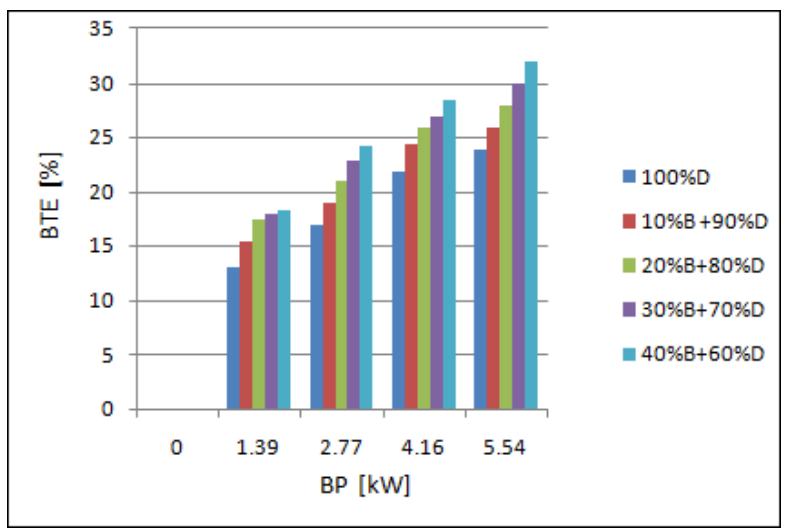

Fig. 5 Comparison of BTE with brake power at inlet air temp $35^{\circ} \mathrm{C}$

Fig. 5 shows the comparison of effect of brake power on brake thermal efficiency between diesel and blends of corn biodiesel at inlet air temperature of $35^{\circ} \mathrm{C}$. It can be observed that brake thermal efficiency of the engine fuelled with biodiesel blends has higher than that of diesel at all the load conditions. The maximum brake thermal efficiency obtained is about $32 \%$ for B 40 . At the brake power of $5.54 \mathrm{~kW}$, the brake thermal efficiency of the engine is about $24 \%$ for $100 \%$ diesel and $28 \%$ for Blend B20. It is evident from Fig. 5 that as the percentage of esterified corn oil in the blend increases, the brake thermal efficiency of the engine increases.

The comparison between brake thermal efficiency and brake power at inlet air temperature of $50^{\circ} \mathrm{C}$ is shown in fig.6. It indicates that the brake thermal efficiency is about $31.2 \%$ for $100 \%$ diesel and $37.5 \%$ for blendB20 at brake power of $5.54 \mathrm{~kW}$. The BTE of the engine fuelled with blend $\mathrm{B} 20$ has increased by $25.33 \%$ when the inlet air temperature was increased from $35^{\circ} \mathrm{C}$ to $50^{\circ} \mathrm{C}$.

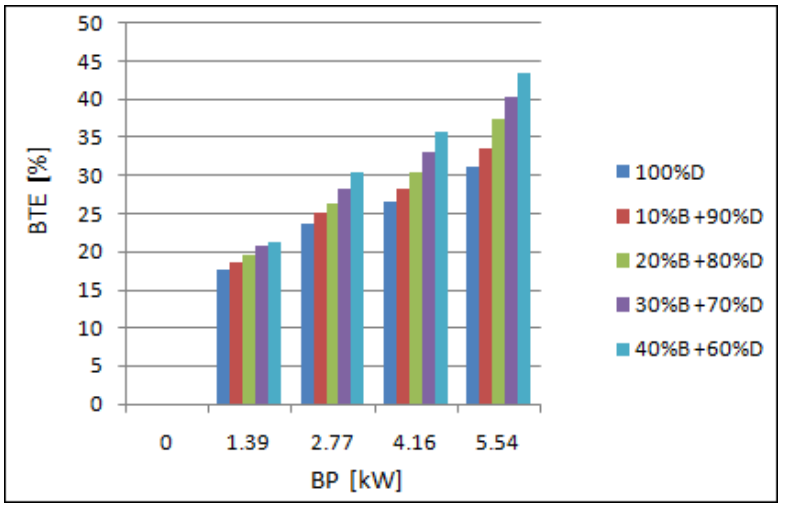

Fig. 6 Comparison of BTE with brake power at $50^{\circ} \mathrm{C}$

\subsection{Indicated thermal efficiency (ITE)}

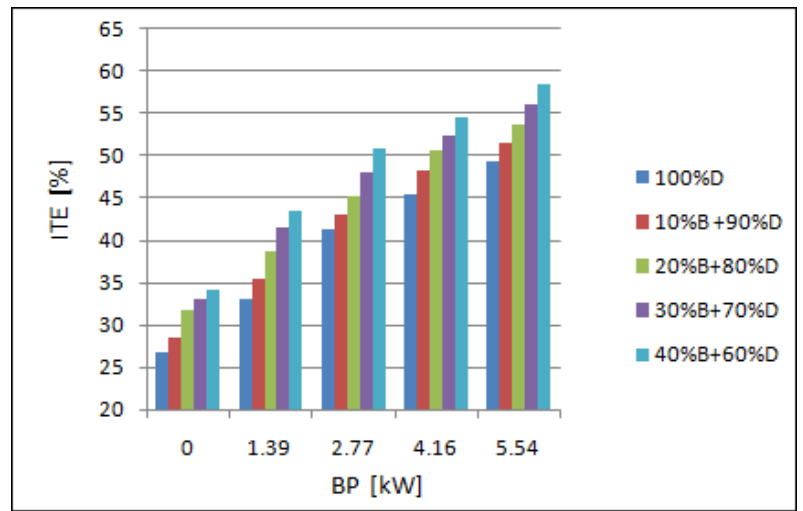

Fig. 7 Comparison of ITE with brake power at $35^{\circ} \mathrm{C}$

Fig.7 displays the comparison of effect of brake power on indicated thermal efficiency at inlet air temperature of $35^{\circ} \mathrm{C}$. Indicated thermal efficiency is gradually increasing with brake power. At the brake power of $5.54 \mathrm{~kW}$, the indicated thermal efficiency is about $49.4 \%$ for $100 \%$ diesel and $53.7 \%$ for blend B20.

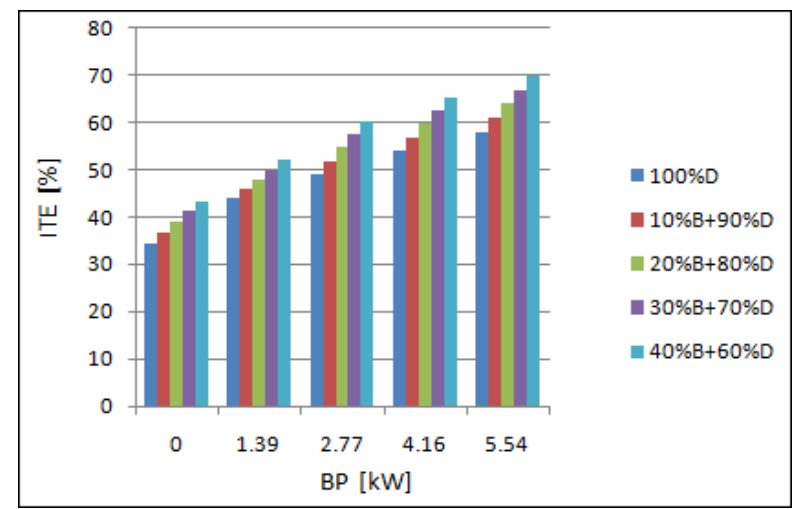

Fig. 8 Comparison of ITE with brake power at $50^{\circ} \mathrm{C}$

Fig. 8 depicts the comparison of effect of brake power on indicated thermal efficiency at inlet air temperature of $50^{\circ} \mathrm{C}$. It can be seen that brake power of $5.54 \mathrm{~kW}$, the indicated thermal efficiency of about $58 \%$ for $100 \%$ diesel and $64 \%$ for blend B20. The ITE is increased from $53.7 \%$ to $64 \%$ when the air inlet temperature was increased from $35^{\circ} \mathrm{C}$ to $50^{\circ} \mathrm{C}$ for blend B20 at a load of $5.54 \mathrm{~kW}$. 


\subsection{Brake specific fuel consumption (BSFC)}

The brake specific fuel consumption (BSFC) can be defined as the mass of fuel burnt to produce $1 \mathrm{~kW}$ power output in an hour. The variation of brake specific fuel consumption with load for different fuels is presented in Fig. 9.It can be observed that the brake specific fuel consumption decreases when the load is increased for both diesel and blends of corn bio diesel. It can also be observed that BSFC tends to decrease when corn biodiesel proportion in the blend is increased for any given load. At the brake power of $5.54 \mathrm{~kW}$, the brake specific fuel consumption is about $0.24 \mathrm{~kg} / \mathrm{kWhr}$ for $100 \%$ diesel and $0.19 \mathrm{~kg} / \mathrm{kWhr}$ for blend B20.

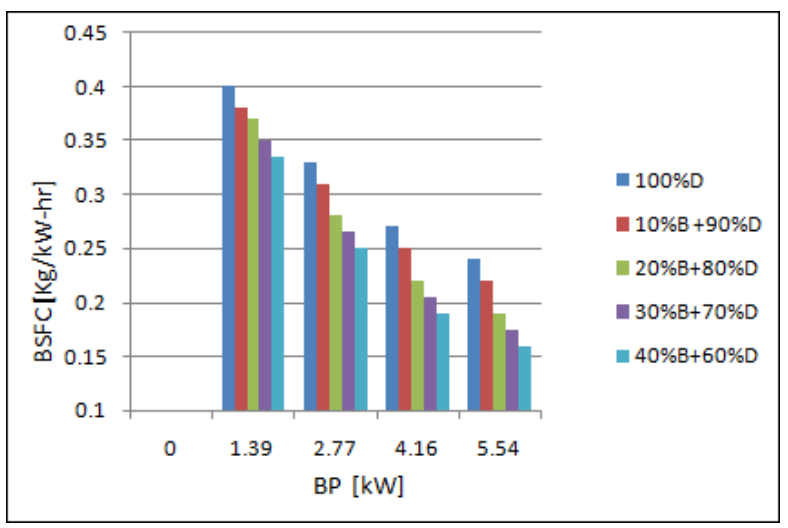

Fig. 9 Variation of BSFC with brake power at $35^{\circ} \mathrm{C}$

Fig. 10 represents the comparison between brake specific fuel consumption and brake power at inlet air temperature of $50^{\circ} \mathrm{C}$. BSFC is about $0.21 \mathrm{~kg} / \mathrm{kWhr}$ for $100 \%$ diesel and $0.19 \mathrm{~kg} / \mathrm{kWhr}$ for blend B20at brake power of $5.54 \mathrm{~kW}$.

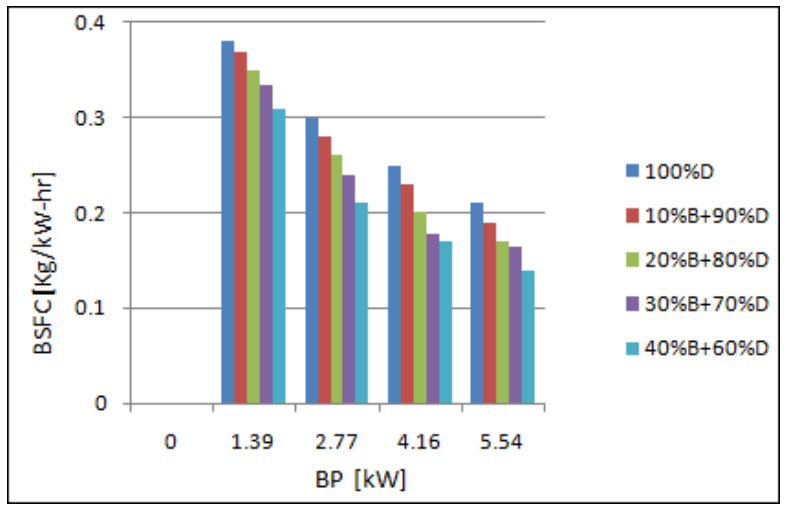

Fig. 10 Variation of BSFC with brake power at $50^{\circ} \mathrm{C}$

\subsection{Exhaust gas emission analysis}

The main difference between esterified bio fuel and diesel is $\mathrm{O}_{2}$ content which enhances the combustion efficiency. Moreover the hydrogen to carbon ratio of biodiesel blend was more than that of diesel fuel which causes the lesser percent of $\mathrm{CO}_{2}$ formation. Fig. 11 show the variation of carbon dioxide for all the tested fuels with respect to brake power at inlet air temperature of $35^{\circ} \mathrm{C}$. At the brake power of $5.54 \mathrm{~kW}$, the Carbon dioxide reaches to $4.8 \%$ for $100 \%$ Diesel and $4.4 \%$ for blend B20. As load increases $\mathrm{CO}_{2}$ tends to increases irrespective of fuels tested.

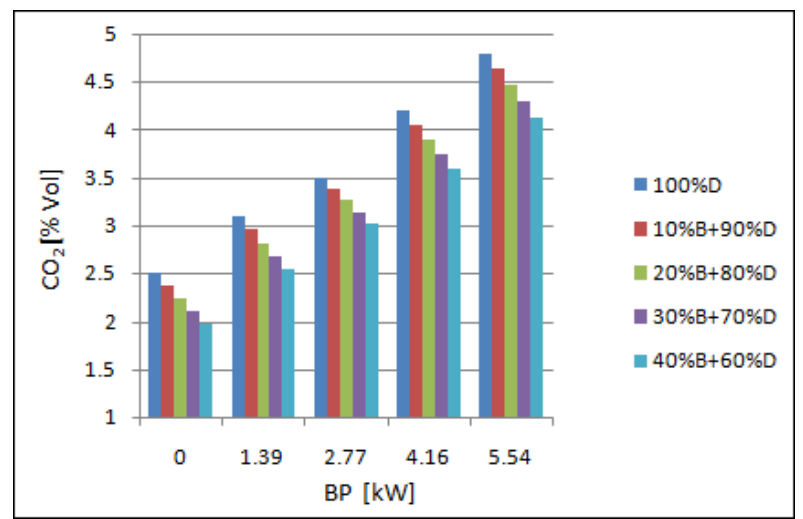

Fig. 11 Variation of $\mathrm{CO}_{2}$ with brake power at $35^{\circ} \mathrm{C}$

The variation of carbon dioxide with brake power at inlet air temperature of $50^{\circ} \mathrm{C}$ is shown Fig. 12. At the brake power of $5.54 \mathrm{~kW}$, the formation of carbon dioxide is $4 \%$ for $100 \%$ diesel and $3.6 \%$ for blend B20. The formation of $\mathrm{CO}_{2}$ is reduced drastically by preheating inlet air.

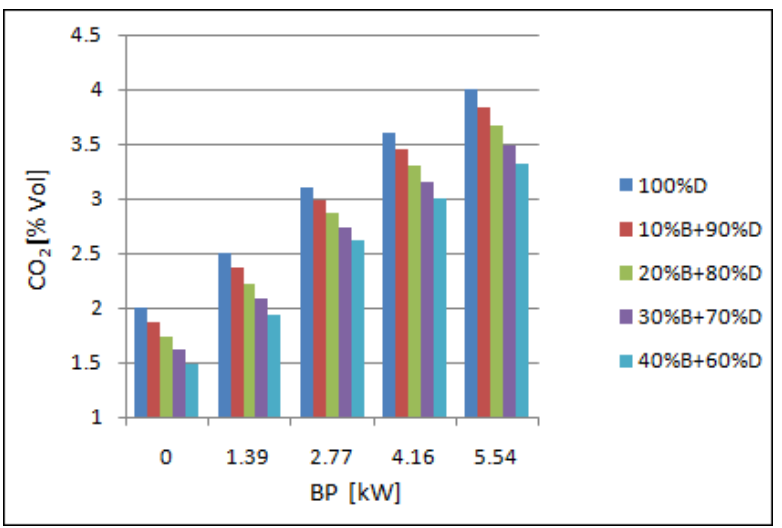

Fig. 12 ariation of $\mathrm{CO}_{2}$ with brake power at $50^{\circ} \mathrm{C}$

The comparison of NOx with brake power at inlet air temperature of $35^{\circ} \mathrm{C}$ is shown in Fig. 12. It can be noted that NOx increases as the load increases for all the fuel tested. From the above Fig we can infer that NOx emission for diesel is slightly higher than the blends of biodiesel at all load conditions. At the brake power of $5.54 \mathrm{~kW}$, the NOx of about 187 ppm for $100 \%$ diesel and 167 ppm for blend B20. It may be due to the fact that the flame temperature for biodiesel was slightly below that of diesel, which causes to reduce the NOx formation. The Ester based blended fuels are having higher cetane number which would reduce the NOx formation.

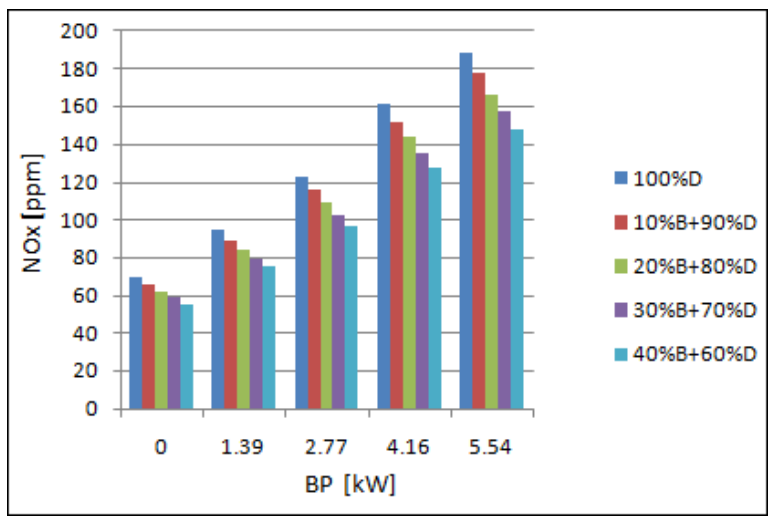

Fig. 13 Variation of NOx with brake power at $35^{\circ} \mathrm{C}$ 
Fig. 14 represents the comparison between NOx and Brake power at inlet air temperature of $50^{\circ} \mathrm{C}$. For brake power of $5.54 \mathrm{~kW}$, the NOx is about $158 \mathrm{ppm}$ for $100 \%$ diesel and 138 for blend B20. The results also clearly demonstrate that the NOx emission decreased with increase in air inlet temperature. NOx is found to have decreased from $165 \mathrm{ppm}$ to $138 \mathrm{ppm}$ when the air inlet temperature was increased from $35^{\circ} \mathrm{C}$ to $50^{\circ} \mathrm{C}$.

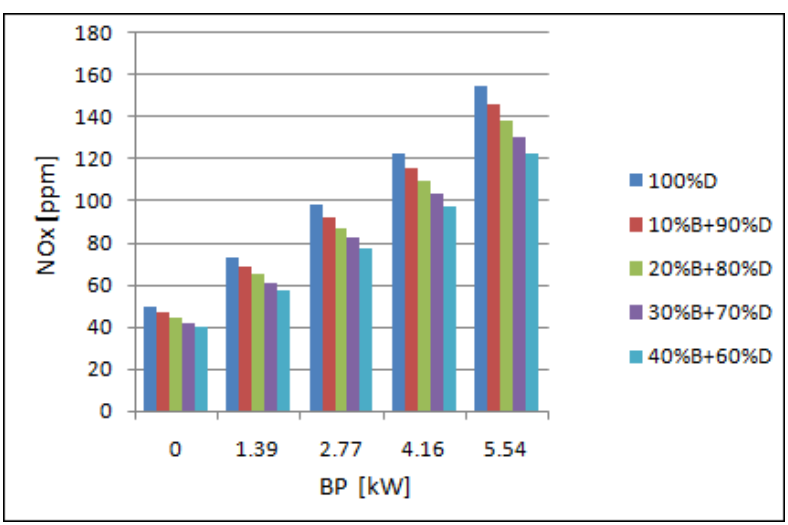

Fig. 14 Variation of NOx with brake power at $50^{\circ} \mathrm{C}$

Unburned hydrocarbons are formed due to the incomplete combustion of the fuel. The formation of unburned hydrocarbon depends on the properties of fuel and fuel /air interaction.

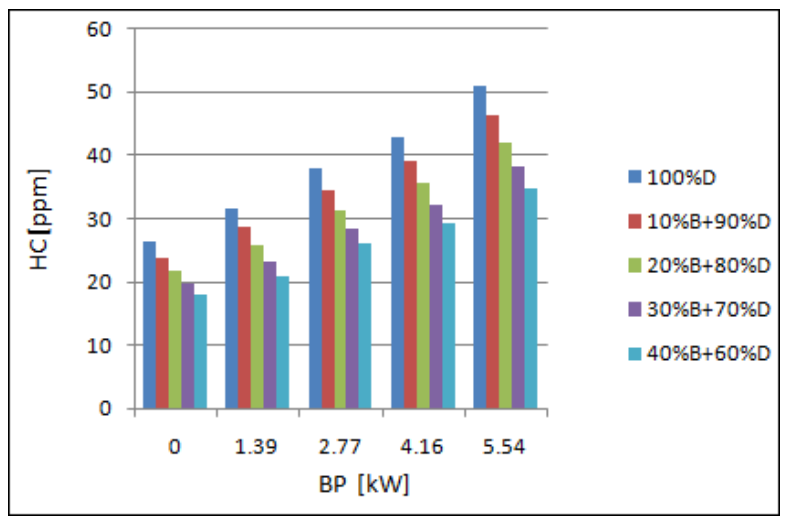

Fig. 15 The variation of hydrocarbon $(\mathrm{HC})$ emission with load for various blends of biodiesel at air inlet temperature of $35^{\circ} \mathrm{C}$

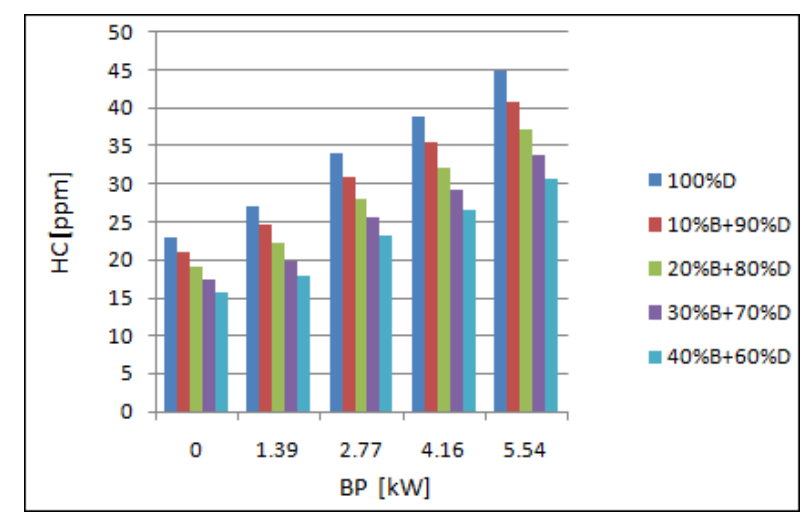

Fig. 16 Variation of $\mathrm{HC}$ with brake power at air temp $50^{\circ} \mathrm{C}$

The variation of hydrocarbon (HC) emission with load for various blends of biodiesel and diesel is depicted in Fig. 15. The HC emission is found to decrease with higher percentages of biodiesel. It can also be noted that biodiesel blends of hydrocarbon has lower than diesel at all the load conditions. At the brake power of $5.54 \mathrm{~kW}$, the hydrocarbon is about $51 \mathrm{ppm}$ for $100 \%$ diesel and $42 \mathrm{ppm}$ for Blend $\mathrm{B} 20$.The reduction of $\mathrm{HC}$ emission is due to higher oxygen content in biodiesel, which enhance the combustion process. Moreover, the higher cetane number of biodiesel reduces the combustion delay or ignition lag which reduces the $\mathrm{HC}$ emission.

Fig. 16 shows the variation of hydro carbon emission of the diesel and various blends of corn biodiesel with respect to various load conditions at air temp of $50^{\circ} \mathrm{C}$. The $\mathrm{HC}$ emissions are found to be increasing with load irrespective of fuels tested. Corn bio diesel blends exhibit lower HC emission compared to diesel irrespective of load applied. Fig. 16 shows that at $5.54 \mathrm{~kW}$ load, the hydrocarbon is about $45 \mathrm{ppm}$ for $100 \%$ diesel and $37 \mathrm{ppm}$ for blend B20. $\mathrm{HC}$ emission is found to have decreased from $42 \mathrm{ppm}$ to $37 \mathrm{ppm}$ when the inlet air temperature was increased from $35^{\circ} \mathrm{C}$ to $50^{\circ} \mathrm{C}$ for the $20 \%$ blend.

The comparison between particulate matter and brake power at inlet air temperature of $35^{\circ} \mathrm{C}$ is graphically represented in Fig. 17. It was noted that biodiesel blends of particulate matter lower than diesel at all the load conditions. At the brake power of $5.54 \mathrm{~kW}$, the PM is about $0.4 \mathrm{gms}$ for $100 \%$ diesel and $0.33 \mathrm{gms}$ for Blend B20.

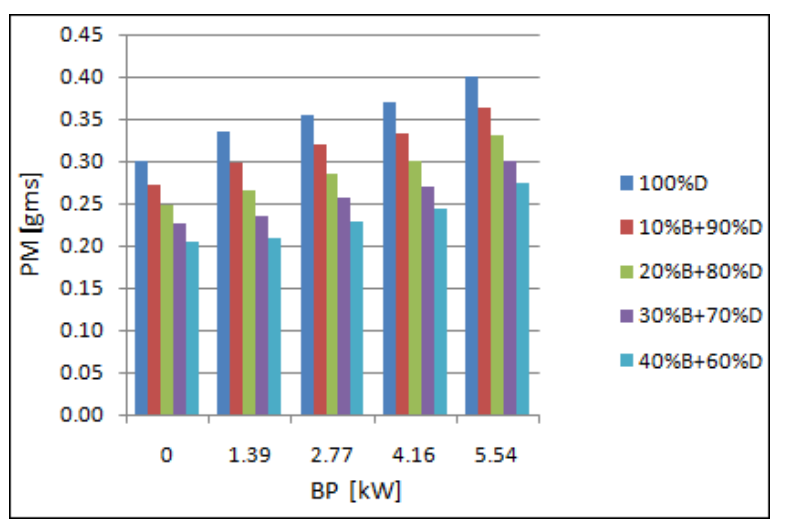

Fig. 17 Comparison of PM with brake power at $35^{\circ} \mathrm{C}$



Fig. 18 Comparison of $\mathrm{PM}$ with brake power at $50^{\circ} \mathrm{C}$

Fig. 18 represents the comparison of particulate matter with brake power at inlet air temperature of $50^{\circ} \mathrm{C}$. For brake power of $5.54 \mathrm{~kW}$, the $\mathrm{PM}$ is about $0.35 \mathrm{gms}$ for $100 \%$ diesel and $0.29 \mathrm{gms}$ for blend B20. The PM emission tends to decrease when the inlet air temperature was increased from $35^{\circ} \mathrm{C}$ to $50^{\circ} \mathrm{C}$ irrespective of bio diesel blend and diesel tested. 


\section{Conclusion}

The performance and emissions of a CI engine have been investigated experimentally using different blends of diesel-corn biodiesel and pure diesel. It is observed that the brake thermal efficiency increases with the increase of biodiesel in the blends of biodiesel and diesel.

Air preheater was employed to increase the inlet air temperature. The thermal efficiency of the engine fuelled with biodiesel blends has higher than that of diesel at all the load conditions. As the percentage of esterified corn oil in the blend increases, the thermal efficiency of the engine increases.

The BTE of the engine fuelled with blend B20 has increased by $25.33 \%$ when the inlet air temperature was increased from $35^{\circ} \mathrm{C}$ to $50^{\circ} \mathrm{C}$.

At the brake power of $5.54 \mathrm{~kW}$, the brake specific fuel consumption is about $0.24 \mathrm{~kg} / \mathrm{kWhr}$ for $100 \%$ diesel and $0.19 \mathrm{~kg} / \mathrm{kWhr}$ for blend B20. Better combustion is achieved due to increase in air inlet temperature, which reduced the formations of unburned $\mathrm{HC}, \mathrm{NOx}$ and $\mathrm{CO}_{2}$.

$\mathrm{HC}$ emission is found to have decreased from $42 \mathrm{ppm}$ to $37 \mathrm{ppm}$ when the inlet air temperature was increased from $35^{\circ} \mathrm{C}$ to $50^{\circ} \mathrm{C}$ for the $20 \%$ blend.

NOx emission for diesel is slightly higher than the blends of biodiesel at all load conditions.

The combination of higher inlet air temperature and corn oil methyl ester has produced solution for energy recovery and an alternative fuel for diesel.

\section{References}

1. Ambarish Datta; Samiddha Palit; Bijan Kumar Mandal 2014. An experimental study on the performance and emission characteristics of a CI engine fuelled with Jatropha biodiesel and its blends with diesel, Journal of Mechanical Science and Technology 28 (5): 1961-1966. http://dx.doi.org/10.1007/s12206-014-0344-7.

2. Belachew Tesfa; Fengshou Gu; Rakesh Mishra; Andrew Ball 2014. Emission characteristics of a ci engine running with a range of biodiesel feedstocks, Energies 7(1): 334-350.

http://dx.doi.org/10.3390/en7010334.

3. De, B.; Panua, R.S. 2015. Performance and emission characteristics of diesel and vegetable oil blends in a directinjection VCR engine, Journal of the Brazilian Society of Mechanical Sciences and Engineering. http://dx.doi.org/10.1007/s40430-015-0349-x.

4. Çelikten, I; Mutlu, E; Solmaz, H. 2012. Variation of performance and emission characteristics of a diesel engine fuelled with diesel, rapeseed oil and hazelnut oil methyl ester blends, Renewable Energy 48: 122-126. http://dx.doi.org/10.1016/j.renene.2012.04.040.

5. Deepak Agarwal; Lokesh Kumar; Avinash Kumar Agarwal 2008. Performance evaluation of a vegetable oil fuelled compression ignition engine, Renewable Energy 33: 1147-1156.

http://dx.doi.org/10.1016/j.renene.2007.06.017.

6. Ekrem Buyukkaya 2010. Effects of biodiesel on a DI diesel engine performance, emission and combustion characteristics, Fuel 89: 3099-3105.

http://dx.doi.org/10.1016/j.fuel.2010.05.034.

7. Jaffar Hussain; Palaniradja, K,; Alagumurthi, N;
Manimaran, R. 2012. Effect of exhaust gas recirculation (egr) on performance and emission characteristics of a three cylinder direct injection compression ignition engine, Alexandria Engineering Journal 51: 241-247.

8. Jinlin Xue; Tony E. Grift; Alan C. Hansen 2011. Effect of biodiesel on engine performances and emissions, Renewable and Sustainable Energy Reviews 15: 10981116. http://dx.doi.org/10.1016/j.rser.2010.11.016.

9. Liaquat, A.M.; Masjuki, H.H.; Kalam, M.A.; RizwanulFattah, I.M.; Hazrat, M.A.; Varman, M.; Mofijur, M.; Shahabuddin, M. 2013. Effect of coconut biodiesel blended fuels on engine performance and emission characteristics, Procedia Engineering 56: 583590.

http://dx.doi.org/10.1016/j.proeng.2013.03.163.

10. Mofijur, M.; Rasul, M.G.; Hyde, J. 2015. Recent developments on internal combustion engine performance and emissions fuelled with biodiesel-diesel-ethanol blends, Procedia Engineering 105: 658-664. http://dx.doi.org/10.1016/j.proeng.2015.05.045.

11. Naga Prasad, Ch.S.; Vijaya Kumar Reddy, K.; Kumar, B.S.P.; Ramjee, E.; Hebbel, O.D.; Nivendg, M.C. 2009. Performance and emission characteristics of a diesel engine with castor oil, Indian Journal of Science and Technology 2(10): 25-31. http://dx.doi.org/10.17485/ijst/2009/v2i10/30714.

12. Nury A. Nieto Garzón; Amir A.M. Oliveira; Ricardo Morel Hartmann; Edson Bazzo 2014. Experimental and thermodynamic analysis of a compression ignition engine operating with straight soybean oil, Journal of the Brazilian Society of Mechanical Sciences and Engineering 37: 1467-1478. http://dx.doi.org/10.1007/s40430-014-0287-z.

13. Paykani, A.; ShervaniTabar, M.T. 2011. Experimental investigation of the effect of exhaust gas recirculation on performance and emissions characteristics of a diesel engine fuelled with biodiesel, International Journal of Engineering and Technology 3:(3): 239-243. http://dx.doi.org/10.7763/IJET.2011.V3.231.

14. Pillay, E. 2012. Engine emissions and performances with alternative biodiesels: a review, Journal of Sustainable Development 5(4): 59-73. http://dx.doi.org/10.5539/jsd.v5n4p59.

15. Pugazhvadivu, M.; Sankaranarayanan, G. 2010. Experimental studies on a diesel engine using mahua oil as fuel, Indian Journal of Science and Technology 3(7): 787-791. http://dx.doi.org/10.17485/ijst/2010/v3i7/29815.

16. Ramesh Kumar; Ankit Sonthalia; Rahul Goel 2011. Experimental study on waste heat recovery from an internal combustion engine using thermoelectric technology, Thermal Science 15(4): 1011-1022. http://dx.doi.org/10.2298/TSCI100518053K.

17. Shravan H. Gawande1; Sunil D. Wankhede; Rahul N. Yerrawar; Vaishali J. Sonawane; Umesh B. Ubarhande 2012. Design and development of shell \& tube heat exchanger for beverage, Modern Mechanical Engineering 2: 121-125.

18. Sivalakshmi, S.; Balusamy, T. 2011. Performance and emission characteristics of a diesel engine fuelled by neem oil blended with alcohols, International Journal of Ambient Energy 32(4): 170-178. http://dx.doi.org/10.1080/01430750.2011.625717. 
19. Venkateswarlu, K.; Murthy, B.S.R.; Subbarao, V.V. 2015. An experimental investigation to study the effect of fuel additives and exhaust gas recirculation on combustion and emissions of diesel-biodiesel blends, Journal of the Brazilian Society of Mechanical Sciences and Engineering. http://dx.doi.org/10.1007/s40430-015-0376-7.

20. Vikas Sharma; Babu, J.M.; Naresh, R.; Gowthaman, S.; Mariappan, R. 2014. Design and fabrication of air preheater for diesel engine, Innovative Design, Analysis and Development Practices in Aerospace and Automotive Engineering, Lecture Notes in Mechanical Engineering, 261-267. http://dx.doi.org/ 10.1007/978-81-322-1871-5_32.

21. Yilmaz, N. 2012. Effects of intake air preheat and fuel blend ratio on a diesel engine operating, Fuel 94: 444447.

http://dx.doi.org/10.1016/j.fuel.2011.10.050.
P. Shanmughasundaram, V. Gopinath, P. Suresh

\section{PERFORMANCE AND EMISSION \\ CHARACTERISTICS OF A DIESEL ENGINE RUNS WITH CORN OIL BIODIESEL BLENDS AND AIR PRE-HEATER}

S u m m a r y

The demand of diesel fuel has been increasing all over the world. To overcome this energy demand, an alternative fuel or biodiesel is the need of the hour. The objective of this work is to investigate the CI engine performance and emission parameters using corn oil Methyl Ester biodiesel fuel.

The engine performance characteristics such as thermal efficiency, brake specific fuel consumption (BSFC), and exhaust emissions such as $\mathrm{CO}_{2}, \mathrm{HC}, \mathrm{NOx}$ and particulate matter were evaluated.

In this experimental work, the diesel engine performance and emission parameters have been investigated with two different inlet air temperature of $35^{\circ} \mathrm{C}$ and $50^{\circ} \mathrm{C}$ for different bio diesel blends like 100\% D, 90\% D+10\% CME (Corn oil Methyl Ester), 80\% D+20\% CME, 70\% D+30\% $\mathrm{CME}$ and $60 \% \mathrm{D}+40 \% \mathrm{CME}$.

Air pre-heater has been designed to preheat the inlet air by using the waste exhaust heat energy coming out of the engine. Higher inlet air temperature causes reduction in the fuel consumption and increasing the thermal efficiency. Corn oil blends with diesel with or without preheating of inlet air can be used in CI engines for obtaining improved engine performance and lower emissions.

Keywords: Air Pre-heater, Corn oil, Inlet air temperature, Performance, exhaust emissions.

Received April 28, 2016 Accepted June 08, 2017 